there are few areas in which substantial savings can occur. Government and funders, too, will need to make a major commitment of additional funding-one-time upgrades to laboratories; ICT (information, communications, and technology); building repair; long-term commitments to quality improvement, faculty recruitment, training, and retention; and enhanced teaching and research facilities. The universities and the ministry will need to make the case to the public for increased higher education funding. Nonetheless, the opportunity to transform higher education exists in Madagascar today in ways it did not even a year ago. The prospects are good for real transformation and quantum improvements in the higher education system as a whole.

\section{A Policy Shift in Botswana's Higher Education Landscape ISAAC N. OBASI}

Isaac N. Obasi is a senior lecturer in the Department of Political and Administrative Studies at the University of Botswana and secretary of the Tertiary Education Research Seminar. Address: Private Bag 0022, Gaborone, Botswana. He is also a regular columnist on higher education for the Daily Champion newspaper, Lagos, Nigeria. E-mail: zikobasi@yahoo.com and obasiin@mopipi.ub.bw.

A country with about I.7 million people, Botswana is generally described by development scholars as an exceptional African success story. Politically it has been a model of democracy on a continent where military dictatorship reigned for too long. It is also an economic miracle, having transformed itself from one of the poorest countries in the world at its independence in 1966 to its present status of a middle-income country. Presently, the country's tertiary education sector consists of one university and a number of other postsecondary institutions. A key feature of its higher education landscape is public ownership and control. However, as elsewhere, the forces of globalization and internal demands for expansion of access are exerting tremendous pressures for change. Consequently, in line with global trends, a new tertiary education policy is being proposed.

\section{Pressures on the Higher Education Landscape}

As the major actor, the government sponsors almost all tertiary education students both at home and abroad through the provision of student loans. Since I990, the government has been spending on average I percent of GDP on tertiary education, which is a reasonably high level compared to other African countries. However, enrollment figures at all tertiary institutions remain below the level of demand for access, with only I2 percent of the I8-24 age cohort presently at the range of institutions (awarding certificates, diplomas, or degrees) - as low as 6.9 percent of the higher education subsector.

The existing order has increasingly come under pressure for change. Proponents cite the inability of the existing university to expand access, which has already led to the idea of a second university. Designated as an international university of science and technology, the new university has been planned to introduce a new market orientation into the higher education landscape. Proponents also cite the overdependence of the university on government funding as both precarious and unsustainable. The decreasing support in the last two years is a danger signal. In the 2005/06 fiscal year, government funding provided about 66 percent of the university's budget.

\section{The Direction of the Emerging Policy}

In 2004, the Tertiary Education Council (TEC) established a Working Group on the Tertiary Education Policy for Botswana. The TEC wants the government to adopt a tertiary education policy that will be "cognizant of global trends and pressures that are impacting on tertiary education in Botswana" and "responsive to specific societal challenges and needs."

For example, some years ago, the University of Botswana implemented a restructuring policy in line with global trends of managerial-oriented leadership, privatization, the outsourcing of such services

Although the TEC proposes wider changes in line with globalization, it also provides an affirmation of some policies and practices that are already in place. For example, some years ago, the University of Botswana implemented a restructuring policy in line with global trends of managerial-oriented leadership, privatization, the outsourcing of such services, and the commercialization of some services. At the level of the state, the government has already adopted some neoliberal policies such as privatization, public-private partnership, and outsourcing of selected services.

In the education sector, the government has cautiously introduced a partial cost-sharing policy at the secondary school level as a testing ground for the future. Furthermore, ownership of tertiary education institutions has been liberalized and the extent of private providers is growing. It is estimated that in 2004, over Ioo private providers registered with the Ministry of Education, mainly for the running of nondegree technical and vocational programs. However, there are other foreign private providers running professional and master's degree programs. For example, the Limkokwing University in Malaysia has been offered registration by the TEC to run both diploma and degree programs. So far only a few private higher education providers have been registered and accredited by the TEC. 


\section{Fear of Losing the "Only Son" Status}

Critics of the envisaged policy fear that funding, academic standards, state sponsorship of students, and the international character of academic staff may be adversely affected when the University of Botswana loses its status as the "only son" in the higher education landscape. Greater reduction of government support may have a negative impact on its ability to retain senior-level expatriate staff and maintain academic standards. Over the years, the University of Botswana has played a critical role in the training of the required manpower for the country's rapid development. The university has attracted expatriate scholars, who constitute 35 percent of its academic staff. It is feared that further reductions in government funding may affect the ability of the university to maintain its competitive edge in Africa. Such a loss of status might challenge the University of Botswana's vision of serving as "a leading academic center of excellence in Africa and the world."

A concomitant issue concerns alternative and sustainable sources of funding. In line with globalization trends elsewhere, the adoption of a cost-sharing policy by the university is a likely option. However, this approach may be more controversial than in other developing countries, for citizens are long used to what a recent report by a government-appointed council (the Business Economic Advisory Council) called "a culture of entitlements" and of living in a "comfort zone." The council's characterization of Botswana as "a relatively low-income country with a high-income lifestyle" does not raise any hope that a cost-sharing policy would be easy to implement.

\section{Violence in Pursuit of}

\section{Knowledge: African Victims of Xenophobia}

\section{Damtew TeferRa}

Damtew Teferra is associate professor (research) of higher education and director of the International Network for Higher Education in Africa (http://www.bc.edu/inhea) at the Center for International Higher Education, Boston College. E-mail: teferra@bc.edu.

$\mathrm{O}$ February 4, 2006, CNN featured horrific pictures of the brutal beating, maiming, and killing of African students by a fringe neo-Nazi group in Russia. While this was one of the major international media to broadcast such a story, in Russia and former Eastern European bloc countries, numerous other attacks on foreign students and scholars, typically Africans and other dark-skinned people, have been reported.

According to an article in the Chronicle of Higher Education
(September 30, 2005), Russia's minister of education and science conceded that the government could not protect foreign students from racist attacks and called on colleges to work more closely with the police in dealing with the widespread problem. In Ukraine, the former president, Leonid Kuchma, once ordered the Ministry of the Interior, the Ministry of Education and Science, and the city administration in Odessa to investigate attacks and killings of foreign students. In the

\section{Earning a medical degree in the former Soviet republics costs only a fraction of expenses in the West, and especially the United States}

former East Germany, students and scholars from Congo, Cameron, Ethiopia, Kenya, Nigeria, Senegal, and Sudan have been beaten, stabbed, killed—and even castrated.

\section{THE Education Market}

Today, around 2.2 million students in the world study outside their borders, and this trend is expected to rise significantly in the next decade. Many of these students study in institutions in the Western hemisphere. While geopolitical developments following September IIth have had some chilling effect on the mobility of students and scholars, this scenario has had a short and temporary impact across the major centers of education.

The former Eastern bloc, led by the former Soviet Union, played an important role in training a considerable number of African students during the Cold War era as part of the broader campaign to build global solidarity and influence. Many African countries sent thousands of students to these countries with full scholarships. With the decline in geopolitical influence, shift in ideology, and consequent lack of interest and capacity to train the African intelligentsia, the number of African students studying in eastern Europe has dropped dramatically.

However, many African students still pursue their studies in this part of the world. For instance, 15,000 students were reported as studying at St. Petersburg, Russia in 2005; as many as 20,000 students now study in Ukraine. Students in eastern Europe are attracted by low tuition and cost of living and relatively lax visa regulations, among other factors. Earning a medical degree in the former Soviet republics costs only a fraction of expenses in the West, and especially the United States. While it has become increasingly onerous to acquire visas for countries in the North, post-September itth, with proper documents visas could be obtained in as short a time as 24 hours in these countries.

\section{Beyond Lip Service}

Most African governments have ignored these growing brutal attacks on their citizens. Only a few governments have expressed their concern and lodged formal complaints through 